\title{
Isolasi dan Identifikasi Bakteri yang Toleran terhadap Fungisida Mankozeb pada Lahan Pertanian Tomat di Desa Tempok, Kecamatan Tompaso, Sulawesi Utara \\ (Isolation and Identification Mankozeb Fungicide-Tolerant on the Tomato Farm in Tempok Village, Tompaso District, North Sulawesi)
}

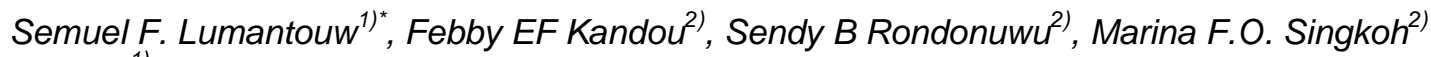 \\ ${ }^{1)}$ Alumni Jurusan Biologi Fakultas MIPA Unsiversitas Sam Ratulangi Manado \\ 2) Jurusan Biologi Fakultas MIPA Universitas Sam Ratulangi Manado \\ Email korespondensi: ferdinan_lumantow@yahoo.com
}

Diterima 31 Juli 2013, diterima untuk dipublikasikan 10 Agustus 2013

\begin{abstract}
Abstrak
Penggunaan fungisida mankozeb secara terus-menerus untuk menangani penyakit yang disebabkan jamur dapat mengakibatkan kerusakan pada lingkungan dan mengganggu kesehatan. Penelitian ini bertujuan untuk mengisolasi dan indentifikasi bakteri yang toleran terhadap fungisida mankozeb yang terdapat pada lahan pertanian tomat di Desa Tempok Kecamatan Tompaso. Penelitian dilakukan dengan cara mengisolasi bakteri pada medium seleksi yang mengandung fungisida mankozeb $10 \%$ selama 2 hari pada suhu $37^{\circ} \mathrm{C}$ kemudian dimurnikan dengan menggunakan medium seleksi yang sama. Setelah didapatkan isolat murni, uji morfologi dan uji biokimia dilakukan. Uji morfologi dan biokimia serta identifikasi menunjukkan ada 3 genus bakteri yang toleran terhadap fungisida mankozeb, yaitu Vibrio sp., Mycobacterium sp., dan Corynebaterium sp.

Kata kunci : koloni, bakteri, fungisida mankozeb
\end{abstract}

\section{Abstract}

The continuous use of mankozeb fungicide to treat diseases caused by fungi can result in the damage of the environment and the community health. This study aimed to isolate and identify the bacteria that are tolerant to mancozeb on the tomato farms in the Tempok Village, Tompaso District. This study was carried out by isolating the bacteria on the selection medium containing 10\% mancozeb for 2 days at $37^{\circ} \mathrm{C}$ and then purifying them using the same medium. After obtaining the pure isolates, the morphological and biochemical tests were conducted. The morphological and biochemical tests as well as the identification indicated that there were 3 genera of mancozeb-tolerant-bacteria,i.e. Vibrio sp., Mycobacterium sp., and Corynebacterium sp.

Keywords : colony, bacteria, mancozeb fungicide

\section{PENDAHULUAN}

Dalam bidang pertanian, pestisida mempunyai peranan penting untuk membantu mengatasi permasalahan organisme pengganggu, bahkan telah menjadi bahan yang sangat penting dalam meningkatkan produksi pertanian (Ware 1983 dalam Saenong 2011). Keberhasilan pestisida dalam peranannya menyelamatkan hasil produksi pertanian ternyata berdampak pada meningkatnya penggunaan berbagai jenis pestisida 
saat ini, diperkirakan mencapai hampir 2,5 milyar $\mathrm{kg}$ per tahun (Sastroutomo 1992). Penggunaan pestisida jenis fungisida di Indonesia menempati urutan ketiga yaitu mencapai 12,05 \% diatas herbisida dan insektisida (Soemirat 2005).

Meningkatnya penggunaan pestisida dapat menimbulkan dampak negatif terhadap lingkungan dan manusia. Pada lingkungan yang tercemar pestisida ada populasi mikroorganisme dapat bertahan hidup dengan cara beradaptasi terhadap kontaminan. Salah satu mikroorganisme yang mampu beradaptasi adalah bakteri. Bakteri beradaptasi terhadap lingkungan yang tercemar dengan cara memecah atau mendegradasi senyawa pencemar menjadi bahan yang kurang beracun atau tidak beracun (Anonim 2007 dalam Warouw 2008). Salah satu pestisida yang dapat didegradasi oleh bakteri adalah fungisida yang memiliki senyawa propineb dan mankozeb. Bakteri memanfaatkan propineb dan mankozeb sebagai sumber karbon, nitrogen, dan energi untuk pertumbuhannya (Asano dan Fujishiro 1982).

Dalam penanggulangan serangan jamur di lahan pertanian tomat di Desa Tempok Kecamatan Tompaso digunakan fungisida mankozeb secara terus menerus. Berdasarkan hal tersebut maka muncul pemikiran bahwa adanya bakteri yang toleran terhadap fungisida mankozeb pada lahan tersebut, sehingga perlu dilakukan penelitian tentang bakteri apa saja yang toleran terhadap fungisida mankozeb dalam rangka mendukung teknologi bioremediasi. Penelitian ini bertujuan untuk mengisolasi dan mengidentifikasi bakteri-bakteri yang toleran terhadap fungisida mankozeb pada lahan pertanian tomat.

\section{METODE}

Pengambilan sampel tanah dilakukan pada lahan pertanian tomat yang menggunakan fungisida mankozeb sebagai pembasmi hama jamur (fungi) di Desa Tempok Kecamatan Tompaso. Penelitian dilaksanakan di Laboratorium Mikrobiologi dan Laboratorium Unit Layanan Bioteknologi Fakultas Matematika dan IImu Pengetahuan Alam. Penelitian ini dilakukan pada bulan Juli sampai Oktober 2012.

Sebelum melakukan penelitian alat-alat dan bahan disterilisasi dengan autoklaf dengan suhu $121^{\circ} \mathrm{C}$ selama 15 menit. Medium yang digunakan untuk isolasi adalah Nutrient Broth (NB), sedangkan medium seleksi yang digunakan adalah Nutrient Agar (NA) yang mengandung $10 \%$ fungisida. Pada pembuatan medium seleksi, pertamatama dibuat larutan 100\% fungisida. Dosis $100 \%$ pemakaian fungisida mankozeb pada lahan pertanian yaitu 1,6 kg Dithane M-45 dilarutkan dalam $400 \mathrm{~L}$ air. Setelah dibuat diencerkan menjadi dosis $10 \%$, maka larutan menjadi $0,16 \mathrm{~kg}$ dilarutkan danlam 40 $\mathrm{L}$ air. Larutan $10 \%$ fungisida mankozeb akan dicampurkan dengan Nutrient Agar (NA). untuk pembuatan medium seleksi, penggunaan fungisida mankozeb $10 \%$ dan Nutrien Agar (NA) disesuaikan dengan kebutuhan pembuatan media.

Pengambilan bakteri dari sampel tanah pada sebanyak $30 \mathrm{~g}$ dari lahan pertanian secara aseptik dari bagian permukaan tanah sampai kedalaman sekitar $20 \mathrm{~cm}$. Sampel tanah yang diambil ditapis melalui penyaringan untuk memisahkan tanah dari batu-batuan dan materi tumbuhan. Sebanyak $5 \mathrm{~g}$ tanah 
ditempatkan pada tabung reaksi untuk proses pengenceran $10^{-3}$. Setelah itu di ambil $0.5 \mathrm{~mL}$, lalu diisolasi pada medium NA yang mengandung 10\% fungisida mankozeb. Setelah itu diinkubasi pada suhu $37^{\circ} \mathrm{C}$ dan diamati setiap hari. Untuk mendapatkan kultur isolat bakteri murni, sekitar 5-10 koloni berbeda yang ditumbuhkan pada medium NA yang mengandung $10 \%$ fungisida, dimurnikan dengan cara streak dan diinkubasi pada suhu $37^{\circ} \mathrm{C}$ selama 2 hari. Koloni yang terpisah kemudian disubkultur pada medium yang mengandung fungisida $10 \%$.

Untuk mengidentifikasi bakteri dilakukan beberapa pengujian yaitu pengujian morfologi dan pengujian biokimia. Pengujian morfologi terdiri dari uji pewarnaan Gram dan uji motilitas sedangkan pengujian biokimia terdiri dari enam uji yaitu uji degradasi tritofan (indol), uji produksi $\mathrm{H}_{2} \mathrm{~S}$, uji fermentasi karbohidrat, uji katalase, uji sitrat, dan uji lisin dekarboksilasi.

\section{HASIL DAN PEMBAHASAN}

Berdasarkan hasil pengujian morfologi (Tabel 1) untuk uji pewarnaan Gram yaitu terdapat 3 isolat bersifat Gram negatif (-) yang ditandai dengan sel berwarna merah muda sedangkan 2 isolat besifat Gram positif (+) yang ditandai dengan sel berwarna ungu. Untuk uji motilitas semua isolat bersifat positif (+) yang ditandai dengan pertumbuhan koloni pada media Motility Test Medium melebar.

Untuk pengujian lanjut dilakukan pengujian biokimia yang terdiri dari enam uji. Berdasarkan hasil pengujian biokimia (Tabel 2) yaitu untuk uji indol pada isolat $A, B, C, D$ dan $E$ bersifat negatif (-) yang ditandai larutnya senyawa amino benzealdehid dalam air sehingga tidak membentuk warna merah seperti cincin sebagai pembentukan indol. Untuk hasil uji $\mathrm{H}_{2} \mathrm{~S}$ pada isolat $\mathrm{A}, \mathrm{B}, \mathrm{C}, \mathrm{D}$ dan $\mathrm{E}$ bersifat negatif (-) yang ditandai dengan tidak terbentuk endapan berwarna hitam pada dasar media Triple Sugar Iron Agar sebagai tanda bakteri dapat menghasilkan $\mathrm{H}_{2} \mathrm{~S}$. Untuk hasil uji fermentasi karbohidrat isolat $A, B, C, D$ dan $E$ bersifat positif (+) yang ditandai dengan dengan perubahan warna pada media Triple Sugar Iron dari warna merah menjadi warna kuning dan pembentukan gas yang ditandai dengan pembentukan rongga udarah pada media. Untuk hasil uji katalase pada isolat $A, B, C$, $D$ dan $E$ bersifat positif (+) yang ditandai dengan pembentukan gelembung udara pada media Nutrien Broth sebagai tanda bakteri dapat membentuk $\mathrm{O}_{2}$ dengan memproduksi enzim katalase lewat degradasi hidrogen peroksida yang dilakukan oleh bakteri. Untuk hasil uji sitrat pada isolat $A, B, C, D$ dan $E$ bersifat positif (+) yang ditandai dengan perubahan warna pada medium Simmons's Citrate Agar dari warna hijau menjadi warna biru karena terjadi peningkatan $\mathrm{pH}$ pada media. Untuk hasil uji lisin dekarboksilasi pada isolat $A, C$, dan $D$ bersifat negatif yang ditandai dengan perubahan warna media menjadi kuning sedangkan pada isolat $B$ dan $E$ bersifat positif yang ditandai dengan perubahan warna pada media menjadi warna violet. 
Tabel 1.Hasil uji pewarnaan Gram, motilitas dan bentuk sel kelima isolate bakteri

\begin{tabular}{ccccc}
\hline No & Isolat & Uji Gram & Uji Motilitas & Bentuk sel \\
\hline 1 & A & - & + & Batang \\
2 & B & - & + & Batang \\
3 & C & - & + & Batang \\
4 & D & + & + & Batang \\
5 & E & + & + & Batang \\
\hline
\end{tabular}

Tabel 2. Hasil uji biokimia dan identifikasi kelima isolat bakteri

\begin{tabular}{ccccccccc}
\hline No & Isolat & Indol & $\mathrm{H}_{2} \mathrm{~S}$ & $\begin{array}{c}\text { Fermentasi } \\
\text { karbohidrat }\end{array}$ & Katalase & Sitrat & $\begin{array}{c}\text { Lysin } \\
\text { Dekarboksilasi }\end{array}$ & Genus \\
\hline 1 & A & - & - & + & + & + & - & Vibrio \\
2 & $\mathrm{~B}$ & - & - & + & + & + & + & Vibrio \\
3 & $\mathrm{C}$ & - & - & + & + & + & - & Vibrio \\
4 & $\mathrm{D}$ & - & - & + & + & + & - & Mycobacterium \\
5 & E & - & - & + & + & + & + & Corynebacterium \\
\hline
\end{tabular}

Berdasarkan hasil pengujian morfologi, pengujian biokimia dan identifikasi dengan menggunakan buku Bergey's Manual of Systematic Bacteriology terdapat 3 genus bakteri yang terdapat pada isolat. Untuk genus bakteri yang terdapat pada isolat $A, B$, dan $C$ adalah bakteri Vibrio sp., meskipun ke-3 isolat mempunyai bentuk koloni dan uji lisin dekarboksilasi berbeda, menandakan adanya perbedaan spesies. Berdasarkan penelitian Felix et al. (2011), didapatkan bakteri Vibrio sp. dengan hasil uji biokimia yang hampir sama dengan hasil uji biokimia isolat $A$, $B$, dan $C$, sehingga diduga bakteri Vibrio $s p$. terdapat pada isolate $A, B$, dan C. Untuk genus bakteri yang terdapat pada isolat $D$ adalah bakteri Mycobacterium sp., ini ditandai dengan pengujian katalase dan uji sitrat bersifat positif $(+)$ serta sel berbentuk batang dan bersifat gram negatif. Menurut Vestal (1977), standar uji biokimia untuk identifikasi bakteri Mycobacterium sp. adalah uji sitrat, uji produksi niacin, dan uji katalase. Dalam penelitian ini hanya dilakukan dua uji dari tiga standar identifikasi Mycobacterium sp. yaitu uji sitrat dan uji katalase. Berdasarkan hasil pengujian pada isolat $D$ sama dengan penelitian yang dilakukan oleh Parashar et al. (2007) yang menemukan bakteri Mycobacterium sp. pada sampel penelitiannya. Untuk genus bakteri yang terdapat pada isolat $E$ adalah bakteri Corynebacterium sp., ini ditandai dengan persamaan dengan penelitian Baya et al. (1992), didapatkan bakteri Corynebacterium sp. pada sampelnya dengan uji morfologi dan biokimia sama dengan hasil uji pada isolat $E$, sehingga dapat diduga bakteri yang terdapat pada isolat $E$ adalah Corynebacterium sp.

Berdasarkan hasil identifikasi terdapat 3 genus bakteri yang bertumbuh pada medium seleksi yang dibuat dari NA ditambah dengan Fungisida berbahan aktif mankozeb yairu Vibrio sp., Mycobacterium sp. dan Corynebacterium sp. Kemampuan bakteri tumbuh pada medium seleksi menunjukan bahwa bakteri tersebut toleran atau resisten terhadap fungsida mankozeb. Degradasi merupakan salah satu aktifitas bakteri untuk bertahan hidup atau toleran terhadap fungisida. Menurut Atlas (1992), proses degradasi adalah perubahan bentuk, baik susunan 
maupun perombakan senyawa tidak stabil menjadi senyawa yang lebih stabil dari semula.

\section{KESIMPULAN}

Berdasarkan hasil pengamatan untuk pewarnaan Gram didapatkan isolat $A, B$ dan $C$ bersifat Gram negatif sedangkan untuk isolat $\mathrm{D}$ dan $\mathrm{E}$ bersifat Gram positif. Untuk uji motilitas, isolat $A, B, C$ dan $E$ bersifat motil sedangkan untuk isolate $D$ besifat nonmotil. Untuk uji biokimia pada isolat $A, B, C, D$ dan $E$ tidak dapat menghasilkan uji produksi $\mathrm{H} 2 \mathrm{~S}$ dan indol sehingga bersifat negatif. Untuk hasil uji fermentasi karbohidrat, katalase, dan sitrat bersifat positif pada semua isolat. Untuk uji lisin dekarboksilasi, untuk isolat $\mathrm{B}$ dan $\mathrm{E}$ bersifat positif sedangkan untuk isolat $A, C$, dan $D$ bersifat negatif.

Berdasarkan hasil dari uji morfologi yang dilanjutkan uji biokimia dan identifikasi maka didapatkan tiga genus bakteri yang toleran terhadap fungisida mankozeb berdosis 10\% dari lahan pertanian tomat di Desa Tempok Kecamatan Tompaso yaitu Vibrio sp., Mycobacterium sp., dan Corynebacterium sp.

\section{DAFTAR PUSTAKA}

Asano Y, Fujishiro K (1982) Aliphatic nitrile hydratase from Arthrobacter sp. Soil Biol. Biochem. 46 (5): 1165-1174

Atlas RM, Bartha R (1993) Microbial ecology fundamental and application. $3^{\text {rd }}$ Edition. The Benjanin Cummings Publising Company Inc. California

Baya. AM, Lupiani B, Bandin I, Hetrick FM, Figueras A, May EM, Toranzo AE (1992)
Corynebacterium aquaticum from culture striped bass 14:115-126

Felix F, Nugroho TT, Silalahi S, Octavia Y (2011) Skrining bakteri Vibrio sp. asli Indonesia. Jurnal IImu dan Teknologi Kelautan Tropis 3:85-99

Parashar D, Ramdas, Chaunan DS, Sharman VD, Lavama M, Yadau VS, Kotoch VM (2009) Identification of environmental Mycobacteria. Department of Health Research. New Delhi

Sastroutomo SS (1992) Pestisida. Dasar-dasar dan dampak penggunaannya. Penerbit PT. Gramedia Pustaka Utama, Jakarta

Soemirat S (2005) Dasar-dasar public relations. PT Remaja Rosdakarya. Bandung.

Soenong MS (2011) Beberapa produk baru insektisida untuk organisme pengganggu tanaman pangan, hortikultura dan tanaman perkebunan. Balai Penelitian Tanaman Serealia. pp. 445-450

Vestal AL (1977) Procedures for isolation and identification of Mycobacterium. Department of Health, Education and Walfare. CDC Atlanta. Georgia

Warouw ZWM (2008) Teknologi bioremidiasi sebagai pembersih lahan tercemar metal merkuri. Jurnal Formas 1:292-301

Ware GW (1986) Fundamentals of pesticides- A self introduction guide. $2^{\text {nd }}$ Edition. Thomson Publication. Fresno 